\title{
THE ROLE OF MUSSĀLAHAH IN CONFLICT RESOLUTION: A HISTORICAL PERSPECTIVE
}

\author{
Rusli \\ IAIN Palu Jl. Diponegoro No. 23 Palu Sulawesi Tengah \\ e-mail: rusli_mochtar@yahoo.com
}

\begin{abstract}
Abstrak. Artikel ini membahas tentang peran muṣālahah dalam resolusi konflik di kalangan masyarakat Muslim dengan menggunakan pendekatan sejarah. Dari analisis sejarah dapat disimpulkan bahwa konsep șulh dan mușālahah telah ditemukan pada masa sebelum Islam, yang dilakukan oleh para klan di masyarakat Arab pra-Islam. Pada periode Islam, seperti dalam kasus Penaklukan Mekkah (Fath Makkah) dan Perjanjian Hudaybiyyah. Dalam pemecahan konflik tersebut, ada beberapa prinsip yang digunakan oleh Nabi, yaitu toleransi, nir-kekerasan, kesabaran, pemaafan, perdamaian, keharmonian, dan kasih sayang.
\end{abstract}

Abstract. This paper deals with the role of mușālahah in conflic resolution among Muslim societies using a historical approach. From a historical analysis it is concluded that the concept of sulh and mușalahah have predated Islam, and played a vital role in resolving disputes and conflicts among clans in pre-Islam Arab societies. In the period of Islam, as in the case of Fath Makkah (winning over Mecca) and Sulh al-Hudaybiyyah (peace treaty at Hudaybiyyah). In resolving conflicts, there are principles employed by the Prophet Muhammad, such as tolerance, nonviolence, patience, forgiveness, peace, harmony and mercy.

Kata Kunci: resolusi konflik, muṣālaḥah, șulh, toleransi, nir-kekerasan, pemaafan 


\section{INTRODUCTION}

Conflict is part of human life. It occurs when two or more people disagree or engage in struggle over certain issues. It is a social necessity and a normal and functional inevitable aspect of the healthy function of all communities. Conflict can take many forms, such as conflict of family, conflict of interests, conflict of ethnic-groups, conflict of religious groups, etc. Despite its positive catalytic potential, conflict is distasteful for many people. The reasons are understandable: first, conflict is unsettling and unpredictable. If poorly handled, it can become negative and destructive; second, confrontation causes many people to react in an unpleasant, defensive and emotionally intense manner. They may "break down," flee, or counter-attack; third, conflict often raises fundamental personal concerns about trust, commitment and acceptance in one's relationship to another. In superiorsubordinate relationships it also raises concerns for career security and professional esteem. ${ }^{1}$

However, there are many ways in dealing with conflict. First, effective communication, as Stockwell, ${ }^{2}$ can manage conflict. Second, mediation can be a tool of resolving conflict, which includes three mediation types: transformative, facilitative, and evaluative. ${ }^{3}$ Third, interactive conflict resolution, which comprises dialogue, conflict analysis and problem solving, can be a good option in resolving conflict. ${ }^{4}$ Fourth, Some of the following approaches may help resolve a conflict, such as avoidance,

\footnotetext{
${ }^{1}$ Ross G Stockwell, "Effective communication in managing conflict," CMA Magazine, Vol. 71, No. 3 (April 1997), h. 6.

${ }^{2}$ Ibid.

${ }^{3}$ Andrew Woolford and R. S. Ratner, "Mediation Frames/Justice Games," in Dennis J. D. Sandole et.al (eds), Handbook of Conflict Analysis and Resolution (London \& New York: Routledge, 2009), h. 315-327.

${ }^{4}$ Ronald J. Fisher, "Interactive Conflict Resolution: Dialogue, Conflict Analysis, and Problem Solving," in Dennis J. D. Sandole et.al (eds), Ibid., h. 328338.
} 
independent action, negotiation, mediation, arbitration, and litigation. ${ }^{5}$

Every religion may have a myriad of ways or methods to deal with this issue. The same also applies to Islam. Islam has many divine ways as stipulated in the Qur'ān and the practice of the Prophet to deal with conflicts and tensions occuring between two different sides-either with Muslims themselves or with other Muslims. So, what is exactly the concept of conflict resolution from the perspective of Islamic law? This paper will analyse the role of musalahah or sulh in resolving conflict in Muslim societies from a historical perspective.

\section{THEOLOGICAL BASIS OF MUȘĀLAHAH}

In Arabic, mușālahah simply means "reconciliation". This term is one of the corner stone concepts of Islam. Although the semantic repertoire of the word musaalahah (reconciliation) is very rich in the Islamic tradition, it is generally accepted that this word derives from the Arabic root sulh which means "peace, reconciliation, and agreement". ${ }^{6}$ The opposite of mușālahah (reconciliation) is fasād (disorder and corruption), ikhtilāf (discord), fitnah (conflict), 'unf (violence).

The Quran constantly warns believers to hold firmly to the notion of musaalahah and to refrain from despondency, ${ }^{8}$ and from malicious or evil behaviour such as benefitting from the weakness of others or using tactics for treacherous and perfidious

\footnotetext{
${ }^{5}$ Sean McCollum, Madinna M. Murphy and Sharon L. Banas, Character Education: Managing Conflict Resolution (New York: Chelsea House, 2009), h. 18-19.

${ }^{6} \mathrm{Abū}$ al-Faḍl Muhammad ibn Mukarram Ibn Manẓūr al-Ifrīqī, Lisān al'Arab, vol. 2 (Beirut: Dār al-Ṣādir, 1374/1955), h. 516-517.

${ }^{7}$ See, al-Mu'allim Buțrus al-Busțānī, Muhịt al-Muḥịt, vol. 2 (Beirut: Maktabah Lubnān, 1386 AH), h. 1198-1199.

${ }^{8}$ The Qur'ān, al-Anfāl (8): 61.
} 
purposes. ${ }^{9}$ Since Allah created the universe in complete order, it is not acceptable for anyone to ruin this harmony by spreading disorder in the universe. ${ }^{10}$ Preservation of this order is a responsibility placed on the shoulders of Allah's highest creation, ${ }^{11}$ namely human beings. From this perspective, the culture of reconciliation is considered as raison d'être (reason for being) of humankind. ${ }^{12}$

Prophet Mohammad also supported șulh. He encouraged people to settle their dispute by șulh. In one of the hadīs reported in Șậ̣̄ al-Bukhārīhe is reported to have said:

$$
\text { ليس الكذاب الذي يصلح بين الناس فينمي خيرا أو يقول خيرا }
$$

"He who makes peace (sulh) between the people by inventing good information or saying good things, is not lair". ${ }^{13}$

The Prophet also upheld the cause of sulh even when certain derogatory remarks were made against him. It is narrated by al-Barā' bin 'Āzib that when Allah's apostle concluded a peace treaty with the people of Hudaibiyah, 'Alī bin Abū Tâlib wrote the document and he mentioned in it, 'Muhammad, Allah's Apostle'. The pagans said, “Don't write: 'Muhammad, Allah's apostle', for if you were an apostle we would not fight with you. Allah's apostle asked "Alī to rub it out, but "Alī said, I will not be the person to rub it out." Allah's apostle rubbed it out and made peace with them on the condition that the Prophet and his companions would enter

${ }^{9}$ Q.S. al-Anfāl (8): 58.

${ }^{10}$ Q.S., al-Rahmān (55): 3-8.

${ }^{11}$ See, Q.S., al-Baqarah (2): 30, 34; Q.S. al-Hijr (15): 29; Q.S. al-Isrā' (17): 61-62, 70 .

${ }^{12}$ See, Q.S. al-Hujurāt (49): 9-10.

${ }^{13} \mathrm{Abū}$ 'Abd Allāh Muhammad ibn Ismā'îl al-Bukhārī, Șậ̄h al-Bukhārī, hadīth no. 2692 (Riyāḍ: Bayt al-Afkār al-Dawliyyah, 1998), h. 513. 
Makkah and stay there for three days, and that they would enter with their weapons in cases. ${ }^{14}$

There are at least two recorded incidents in which the Prophet mediated between two warring parties.

Narrated Sahl ibn Sa'ad: There was dispute amongst the people of the tribe of Banī 'Amr ibn 'Awf. The Prophet went to them ... in order to make șulh (peace) between them. ${ }^{15}$

The companions of the Prophet also encouraged sulh. For example, in the famous letter written by 'Umar ibn al-Khaț̣āb to Abū Mūsā al-Ash'arī, the latter's appointment as a judge contained several principles relating to sulh:

"All types of compromise and conciliation are permissible except those which makes harām anything which is halāl and a halāl is harām".

In the above letter, the part relating to harām and halāl in compromise is based on a hadith of the Prophet: it is narrated by 'Á'ishah that Allah's apostle said, "If somebody innovates something which is not in harmony with the principles of our religion, that thing is rejected." ${ }^{17}$

Mediation and conciliation under Islamic law are conducted in an informal manner without being governed by any formal rule, as is the ever increasing trend in the modern institutional mediations. Informalism is found to be a useful thing which helps the process of settlement.

The only rule which governs sulh in Islamic law is that no compromise is possible in the domain of huqūq Allāh (Rights of Allah) which include hudūd punishment, zakāh (alms giving), kaffārah, etc. Any effort circumvents the provisions prescribed

\footnotetext{
${ }^{14}$ Ibid., hadīs no. 2698; See also Aishath Muneeza, "Is Conventional Alternative Dispute Resolution to Islamic Law," MLJvol. xcvii, no. 4 (2010).

${ }^{15}$ Al-Bukhārī, Șaḥịh al-Bukhārī, hadìth no. 2693.

${ }^{16}$ See, for example, D.S. Margolith, "Omar's Instruction to the Qadi," Journal of Royal Asiatic Society, 307 (1910), h. 311-312.

${ }^{17}$ Al-Bukhārī, Șahīḥ al-Bukhārī, hadīth no. 2697, 514.
} 
for this through mutual settlement is sinful and avoid. In huqūq al-ibād (rights of human being) however compromise and conciliation is not only possible but preferable, so long it is equitable and just and does not violate any provision of shariah. If the matter is already before the court, it has been made.

\section{HISTORICAL SKETCH OF MUȘĀLAHAH}

\section{Pre-Islamic Șulh}

Sulh, or conciliation and peacemaking, is a practice that predated Islam. Within the framework of tribal Arab society, chieftains (shaykhs), soothsayers and healers (kuhhān), and influential noblemen played an indispensable role as arbiters in all disputes within the tribe or between rival tribes. The authority and stature of those men served as sanctions for their verdicts. ${ }^{18}$ The decision of the hakam was final but not legally enforceable. It was an authoritative statement as to what the customary law was or should be and later of Islamic principles. In fact, Schacht refers to a hakam in such situations as 'a lawmaker, an authoritative expounder of the normative legal custom or sunna. ${ }^{19}$ The main objective of these third parties was conciliation and the maintenance of harmony. Some arbitrators would go to a great extent to produce the necessary compensation or inducement out of their own pockets in order to persuade the feuding parties to agree to a șulh.

The effectiveness of tribal mechanisms in containing disputes can be attributed to a 'complex system of special customs and regulatory procedures within each group'. ${ }^{20}$ The concept of

\footnotetext{
${ }^{18}$ M. Hamidullah, “Administration of Justice in Early Islam," Islamic Culture, vol. 11 (1937), h. 163.

${ }^{19}$ Joseph Schacht, An Introduction To Islamic Law (Oxford: The Clarendon Press, 1964), h. 8.

${ }^{20}$ A.S.S. Owidi, "Bedouin Justice in Jordan: The Customary Legal System of the Tribes and its Integration into the Framework of State Polity from 1921 onwards," (Ph.D Dissertation, University of Cambridge, 1982), h. 40.
} 
collective responsibility offered all individuals a measure of protection. However, collective responsibility is a two edged sword. On the one hand, it could potentially turn a conflict between two individuals into a war between two families or tribes and on the other hand, the knowledge that a person's actions might drag the whole tribe into a bloody conflict could also restrain individuals. When a crime is committed, collective responsibility facilitates quick settlement, as the culprit's entire tribe are liable to pay compensation to the victim's family. Compensation, in cash or in kind, is the chief means of settling disputes, hence the existence of elaborate protocols of compensation. Third parties stood to gain much in terms of prestige if their intervention and wasta led to the settlement of a dispute.

According to Islamic sources, the Prophet Muhammad started to play the role of a conciliatory while he was still young. One such example was his enthusiastic participation, at the age of twenty, in the formation of a noble alliance and a pact of chivalry known as hilf al-Fudūl, which he cherished throughout his life with profound memory.

In the years preceding the pact, the Quraysh were invoved in intermittent conflict as a result of an unsettled murder. A Yemini merchant from Zabid had sold some goods to a notable member of the clan of Sahm. Having taken possession of the goods, the man from Sahm refused to pay the agreed price. The wrong doer knew very well that the merchant had no confederate or kinsman in Mecca, whom he could count upon for help. But the merchant, instead of letting it pass, appealed to the Quraysh to see that justice was done. In response a meeting was hosted at the house of 'Abd Allāh ibn Ja'dān. At the meeting, various chiefs and members of tribes pledged to respect the principles of justice, and collectively intervene in conflicts to establish justice. 
To make the pact imperative and sacred, the members went into the Ka'bah and poured water into the receptacle so it flowed on the black stone. Thereupon each man drank from it. Then they raised their right hands above their heads to show they would stand together in this endeavor. The pact was written and placed inside the Ka'bah, the place where the participants believed it would be under the protection of God. Among the members who agreed to the terms of the pact was the Islamic prophet Muhammad. Later on, after proclaiming Islam, Muhammad still acknowledged the validity of the pact, ignoring the fact that most of the members were non-Muslim. Abu Bakr is also said to have agreed to this pact. This presumption is based on the fact that 'Abd Allāh ibn Ja'dān, whose house was the venue for this pledge, was Abū Bakr's fellow clansman. Amongst the clans, Banū Hāshim, Banū Zuhrā and Banū Taym participated in its formation. Neither the Banū Nawfal, nor the powerful Banū Umayyah took part in it.

That pact marked the beginning of some notion of justice in Mecca, which would be later repeated by Muhammad when he would preach Islam. The pact holds significance in Islamic ethics, and represents Islam's interest in human rights and protection of such rights.

\section{Muṣālaḥah in the Islamic Period}

The practice of mușālahah in the Islamic period can be clearly seen in such cases as Fath Makkah (Winning over Makkah) and Sulh al-Hudaybiyah (treaty of peace at Hudaybiyah).

Eight years had passed under perishing threats of war, when one day, these scorned people returned to their hometown with the Prophet as victorious soldiers. Everyone waited nervously to see how the Prophet would treat the Makkan foes. However, the Prophet was deeply concerned about the safety and welfare of Makkans. 
The hadīth as well as historical sources describe specifically how the people of Makkah were very apprehensive and extremely concerned about their fate. Yet the Prophet assured them of safety, announcing that those who entered the House of Allah (Ka'bah), the house of Abū Sufyān [Șakhr ibn Ḥarb ibn Umayyah (57BH-32AH/567-653)] (one of the leaders of Makkan pagans who later became a Muslim), and also those who remained in their own homes would be safe. Many of them had chosen to enter the Ka'bah and were waiting for the Prophet.

As the Messenger of Allah entered the Kabah, he prayed and thanked Allah. Then he glanced at the people around him and asked, "what do you think and say about my treatment of you?" They replied as if in chorus, "We believe and declare that you are a good, kind and generous man, and that you are the brother and the son of a kind man. You are a man of wisdom hence you know what to do. We have no doubt that you will treat the people of Makkah with generosity, forgiveness and compassion." The Prophet then made the historic statement which defines tolerance and reconciliation at its peak: "I shall say to you what the Prophet Yūsuf (Joseph) said to his brothers following their illtreatment against him," he then continued by quoting the declaration of the Prophet Yüsuf revealed in the Quran as follows:

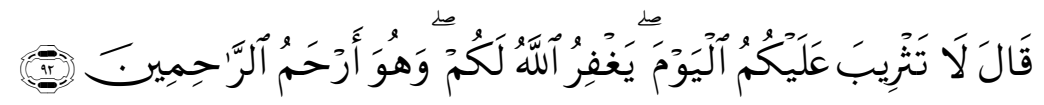

"Have no fear this day! May Allah forgive you, and He is the Most Merciful of those who show mercy." (QS. Yūsuf [12]: 92).

And then the Prophet told to them: اذهبوا فأنتم الطلقاء (Go ahead now you are all free). It is reported that upon listening to the verdict of the Prophet, they all came out of their places of hiding and entered the fold of Islam. The compassionate attitude and the noble declaration of the Prophet clearly meant that he was 
opening a new page in the history. He further expressed firmly that their mistakes, crimes and many other injustices were now under his feet. At the end of his speech, the Prophet reminded them that human beings originally came from Prophet Adam and Adam (peace be on him) was created by Allah out of clay, so it was meaningless to be arrogant about their ancestors. What really mattered were the acts of goodness $(\operatorname{taq} w \bar{a})$ and the deeds of virtue (al-a'māl al-șāliḥah).

The conquest of Makkah provides precious inspiration to those who wish to show great kindness, tolerance and want to compensate and make amends for previous misdeeds and actions. This was the real victory in a sense, where the relation between the Makkan Pagan oppressors and the oppressed Muslims were truly established, and it teaches humanity how to drive out hatred and enmity. The creation of a peaceful atmosphere and rapprochement between two sides is a genuine precaution we can take against the deceitful plots of Satan.

Another case of mușālahah in the Prophet's era is Sulh alHudaybiyah, at treaty of peace which occurred at Hudaybiyah. ${ }^{21}$ This reconciliation took place between the Prophet Muhammad who was also the head of the city state of Madinah and the Quraysh, leaders of the pagan autocracy of Makkah, in the early days of Żu al-Qa'dah $628 \mathrm{M}$ at the place of al-Hudaybiyah near Makkah at the limits of the sacred territory of harām. When the news of the departure of the Prophet from Madinah accompanying with 1500 followers, ${ }^{22}$ reached the Quraysh, they decided to stop Muhammad and his companions even by extending armed resistance. The attitude and behaviour of the

\footnotetext{
${ }^{21}$ Nisar Ahmad, "Peace and Reconciliation, Its Significance and Role in the Mission of the Prophet (Peace be on Him): The Case of Sulh alHudaybiyyah, A Qur'ānic View," Insights, Vol. 2, No. 3-4 (Winter 2009- Spring 2010), h. 181-218.

${ }^{22}$ Abū al-Ḥasan 'Alī al-Nadawī, al-Sīrah al-Nabawiyyah (Jaddah: Dār alShurūq, 1989), h. 274.
} 
Quraysh was quite objectionable and against all norms and prevailing Arabian culture, but the Quraysh decided to check and obstruct the Prophet and Muslims approaching for 'umrah.

The Prophet, in contract, was very much kind and merciful. The news of the Quraysh's gathering army at Dhū Tuwā and sending a two hundred strong cavalry which was approaching Kurā' al-Na'īm to obstruct Muslim progress towards Makkah, did not irritate the Prophet and he showed no resentment. He had every intention to avoid any sort of clash with the Quraysh to save human lives and achieve his objective of peacefully performing umrah. Thus he very intelligently and swiftly diverted his caravan from the normal route to an unusual route, in spite of its being difficult, rocky and sandy, to proceed further. $\mathrm{He}$, therefore, seeking assistance of some of his companions, followed this rugged, rocky and uneven track and successfully avoiding the armed conflict reached al-Hudaybiyah and encamped there, finding a very small source of water (well) to cater the needs of a large gathering.

The Prophet made made it clear that he had not come for any war or other motives, but to venerate the House of Allah and to perform 'umrah. However, the Quraysh sent forty or fifty armed men in order to surround the camp of the Prophet at alHudaybiyah and attack on the companions with stones, arrows and pears to irritate the Muslims to pick up an armed conflict. But all these were caught without any bloodshed and brought before the Prophet, who forgave them and let them go their way.

In continuation of his efforts for reconciliation and pursuing the peace process, the Prophet at last sent 'Usmān ibn 'Affān (d. 35/656) as an official envoy to the Quraysh with a written suggestion to resolve the matter peacefully and smoothly. But they detained 'Uśmān unnecessarily for such a long time that it caused great anxiety in the Muslim pilgrims at al-Hudaybiyah so much so that a rumour of unlawful killing of 'Uṡmān spread out 
and reached the Prophet and the believers, that hurt them all immensely.

The news upset every one, particularly the Prophet. They were left with no option but to take the revenge of 'Uṡmān's blood, without delay, to safeguard the ancient humane tradition of the immunity for the envoys. So, the Prophet announced that he would not leave Makkah until the vengeance of his envoy was taken. The Quraysh chiefs, nobles, and leaders got unnerved, rather frightened. They found no option but to send Suhayl ibn 'Amr for negotiations, to diffuse the grim situation and to avoid immediate clash.

Negotiation started with the representative of the Quraysh but took long time in view of Suhayl's his agitating manner. However, at last reconciliation was reached at and a peace treaty came into being which was properly written, recorded and witnessed by all present there at al-Hudaybiyah. The main clauses of the treaty may be summed up in the following points:

- That there shall be no war between both the parties, the Muslims and the Quraysh for ten years (of time).

- That whoever (man or tribe) wants to enter into a covenant and alliance with Muhammad is allowed to do so and whosoever wants enter into a covenant and alliance with the Quraysh is also allowed to do so.

- That whoever of the Quraysh comes to Muhammad without permission of his guardian, Muhammad is to send him back to them. Whoever of those with Muhammad comes to the Quraysh he is not to be sent back to him.

- That you [Muhammad and his followers] are to withdraw from us [Quraysh] this year and not enter upon us in Makkah, and when next year comes, we shall go out for you and you shall enter it (Makkah) with your companions and will stay in 
it three days. You shall have the arms of a rider, swords in scabbards and you shall not enter it with any thing else.

In view of the terms and conditions of the treaty, the environment in which it was concluded and attitude of the Qurayshite emissary, it seemed that the said treaty was more in favour of the Quraysh than that of the Muslims. However, the Prophet was calm, cool and peaceful, because he was in fact, sincerely translating the commandments of Allah into action with full devotion thus he consoled such uncomfortable companions and explained to them, "I am only a bondman of Allah and His Messenger, I cannot deviate from the divine instructions nor can I entertain any doubt for divine support." This comment of the Prophet normalised the situation.

\section{THE PRINCIPLES OF MUȘĀLAHAH IN RESOLVING CONFLICT}

\section{Muṣālaḥah from Islamic Law Perspective}

Collectivity has a special sanctity attached to it in Islam that resulted in a duty being imposed on any person who has been chosen to resolve a dispute between parties to try to reconcile them first and foremost. The Qur'ān encourages parties to use sulh in order to resolve their disputes: "reconciliation between them, and reconciliation is better" 23 and in another aye "If two parties among the Believers fall into a quarrel, make ye peace between them ... make peace between them with justice, and be fair: For God loves those who are fair and just." ${ }^{24}$

The Prophet Mohammad also insisted on șulh and said it was more rewarding than fasting, praying and offering charity. The Prophet encouraged compromise and mediated both public disputes, such as those between fighting clan members, and private ones, including those between his Companions and their creditors. Further, a well-known hadith of the Prophet warns:

${ }^{23}$ QS. al-Nisä $(4): 128$.

${ }^{24} \mathrm{QS}$. al-Ḥujurāt (49): 9. 


$$
\begin{aligned}
& \text { إنما أنا بشر مثلكم وإنكم تختصمون إليّ، فلعل بعضكم أن يكون ألحن بحجته من } \\
& \text { بعض فأقضى له على نحو ما أسمع منه، فمن قضيت له بشيء من حق أخيه فلا } \\
& \text { يأخذ منه شيئا، فإنما أقطع له قطعة من النار }
\end{aligned}
$$

You bring me lawsuits to decide, and perhaps one of you is more skilled in presenting his plea than the other and so I judge in his favour according to what I hear. He to whom I give in judgment something that is his brother's right, let him not take it, for I but give him a piece of the Fire. $^{25}$

Sulh was the method preferred by the Prophet, who made it plain that he was sceptical of judicial proceedings, which were devised by man and therefore fallible. Parties who won their cases by dent of eloquence at the expense of truth were threatened with direst sanctions. ${ }^{26}$ Thus, the trial process is not regarded as an ultimate truth-finding mechanism that will lead to substantive justice. It can be tainted and subverted by the imperfect nature of man, therefore, it should be avoided when possible.

In Islamic law, there is another kind of sulh which is called tahkīm (arbitration). Many of the Qur'ānic authority and hadīths supporting arbitration could also be used as authority for sulh. The Qur'ān and the Sunna have approved arbitration in the form of a third person chosen by the parties to resolve their disputes either through conciliation or adjudication. However, the differences between the two are also recognised. Arbitration, in Islam, differs from șulh in three respects:

First, in sulh an amicable settlement may be reached between the parties with or without the involvementof others, whereas in arbitration the appointment of a third party is

${ }^{25}$ Mālik ibn Anas, al-Muwațta', vol. 3, Kitāb al-Aqdiyyah [book of judgement], hadith no. 1525 (Rubay: Majmū'ah al-Furqān al-Tijāriyyah, 2003), h. 525.

${ }^{26}$ A. Othman, “'And Amicable Settlement Is Best': Sulh and Dispute Resolution in Islamic Law," Arab Law Quarterly, vol. 21 (2007), h. 64. 
indispensable. However, the disputing parties in șulh, also have the option to use an arbitrator in order to work towards a settlement. Thus, arbitration can be one of the means of sulh. Second, the agreement of sulh is not binding unless it has taken place before the court, whereas arbitration, according to the majority of jurists, is binding without court intervention. And third, sulh can only be resorted to if the dispute has already occurred, i.e., sulh cannot address a prospective dispute, whereas arbitration can address both existing and prospective disputes. ${ }^{27}$

\section{The Principles on Which Conflict Resolution is Based}

Clearly, examples of tolerance and reconciliation are not limited to the events which took place during the conquest of Makkah. Nonetheless, tolerance, forgiveness and reconciliation do not mean the acceptance of passivism. However, despite the existence of hardship and suffering, one can find a way to be active without recourse to disorder and violence. As long as human beings have love of others in their hearts, they become a mirror of Allah's Mercy and Power on the earth. Because Islam made love a virtue and justice as prima condition, it is necessary to live in pursuit of these sublime aims. The Prophet warns Muslims that 'the first thing to be removed from the hearts of people is concord and affection.'

The Prophet's forgiveness and tolerance is beyond any limitation. Allah has attributed and commissioned him to be the mercy for the worlds. He always represented the middle way in his every action. Furthermore, for the sake of individual and communal peace, the Prophet Muhammad encouraged Muslims to sacrifice some of their rights in order to find long-lasting solutions between disputes. Mercy and tolerance is the real Qur'ānic antidote for reconciliation. A strong society is based on

${ }^{27}$ See Aseel Al-Ramahi, "Sulh: A Crucial Part of Islamic Arbitration," Research Paper in Islamic Law and Law of the Muslim World, (New York Law School, 2008), h. 12. 
strong relations between its members. In such societies, arguments, disputes and quarrels wait to be removed by self sacrificing and altruistic people. In modern communities, the need for such a peaceful environment is great and the present author opines that people who wish to live happily in this world have to learn to implement the Prophetic process of love, tolerance and reconciliation appropriately. Tolerance or forgiveness is not a tool to deny or re-interpret what happened, covering up the events, devaluing the targets in a way we wish; on the contrary, it is a pledge stating that the mistakes of the past would not becommitted again. It also reminds us that forgiving the oppressor is a virtue. It is important to bring just and peaceful solution to the social and psychological wounds of the people.

Equally, internalising the values and virtues of patience and dignity and working hard for the sake of peace, reconciliation and harmony among the community are very important. It is worth mentioning here a Qur'ānic injunction which significantly relates to the issue at hand. Allah the almighty commands:

The Believers are but a single brotherhood: so make peace and reconciliation between your two (contending) brothers; and be ever conscience of Allah, that you may receive Mercy. ${ }^{28}$

As the verse indicates, the Islamic understanding of tolerance and reconciliation can provide significant insight for the challenges faced by every kind of people today. It is important to note that the Arabic word mușalahah (mutual reconciliation) indicates that both sides have to make an effort to go forward in this process.

\section{CONCLUSION}

This paper is about the role of musaalahah in conflict resolution which is discussed from a historical perspective. From the above discussion, it can be concluded that from a historical

\footnotetext{
${ }^{28}$ QS. al-Hujurāt (49): 10.
} 
perspective, conflict resolution have been carried out in variety of forms such as sulh (reconciliation) and tahkim (arbitration). In resolving conflict, Islam employs such principles as tolerance, peace, mercy, harmony, non-violent, forgiveness, patience, and mercy.

\section{BIBLIOGRAPHY}

Abū 'Abd Allāh Muḥammad ibn Ismā̄êl al-Bukhārī, Șahịh alBukhārī, ḥadīth no. 2692 (Riyāḍ: Bayt al-Afkār al-Dawliyyah, 1998), 513.

Ahmad, Nisar. "Peace and Reconciliation, Its Significance and Role in the Mission of the Prophet (Peace be on Him): The Case of Șulh al-Hudaybiyyah, A Qur'ānic View." Insights. Vol. 2. No. 3-4 (Winter 2009- Spring 2010).

Al-Ramahi, Aseel. "Sulh: A Crucial Part of Islamic Arbitration." Research Paper in Islamic Law and Law of the Muslim World, (New York Law School, 2008).

Anas, Mālik ibn. al-Muwatța'. vol. 3, Kitāb al-Aqdiyyah [book of judgement], hadith no. 1525. Rubay: Majmū'ah al-Furqān alTijāriyyah, 2003.

al-Bukhārī, Abū 'Abd Allāh Muhammad ibn Ismāî̀l. Șaḥīh alBukhārī. Riyāḍ: Bayt al-Afkār al-Dawliyyah, 1998.

al-Busțānī, al-Mu'allim Buțrus. Muḥiț al-Muḥịt. vol. 2. Beirut: Maktabah Lubnān, 1386 AH.

Fisher, Ronald J. "Interactive Conflict Resolution: Dialogue, Conflict Analysis, and Problem Solving," in Dennis J. D. Sandole et.al (eds). in Dennis J. D. Sandole et.al (eds). Handbook of Conflict Analysis and Resolution. London \& New York: Routledge, 2009.

Hamidullah, M. “Administration of Justice in Early Islam.” Islamic Culture. vol. 11 (1937). 
Manẓūr, Abū al-Faḍl Muhammad ibn Mukarram Ibn. Lisān al'Arab. vol. 2. Beirut: Dār al-Șādir, 1374/1955.

Margolith, D. S. “Omar's Instruction to the Qadi." Journal of Royal Asiatic Society. 307 (1910).

McCollum, Sean, Madinna M. Murphy and Sharon L. Banas. Character Education: Managing Conflict Resolution. New York: Chelsea House, 2009.

Muneeza, Aishath. "Is Conventional Alternative Dispute Resolution to Islamic Law," MLJvol. xcvii, no. 4 (2010).

al-Nadawī, Abū al-Ḥasan. 'Alī al-Sīrah al-Nabawiyyah. Jaddah: Dār al-Shurūq, 1989.

Othman, A. “'And Amicable Settlement Is Best': Sulh and Dispute Resolution in Islamic Law." Arab Law Quarterly. vol. 21 (2007).

Owidi, A. S. S. "Bedouin Justice in Jordan: The Customary Legal System of the Tribes and its Integration into the Framework of State Polity from 1921 onwards," (Ph.D Dissertation, University of Cambridge, 1982).

Schacht, Joseph. An Introduction To Islamic Law. Oxford: The Clarendon Press, 1964.

Stockwell, Ross G. "Effective communication in managing conflict." CMA Magazine, Vol. 71, No. 3 (April 1997), 6.

Woolford, Andrew and R. S. Ratner. "Mediation Frames/Justice Games." in Dennis J. D. Sandole et.al (eds). Handbook of Conflict Analysis and Resolution. London \& New York: Routledge, 2009. 